\title{
Pengujian Metode Kuantitasi Untuk Melakukan Kompresi Citra RGB
}

\author{
Pilipus Tarigan ${ }^{* 1}$, Zekson Arizona Matondang ${ }^{2}$ \\ 1,2 STMIK Kristen Neumann Indonesia, Jl Jamin Ginting Km 10,5 20122 Sumatera Utara,Indonesia. \\ pilipustarigans@gmail.com ${ }^{1}$,zekson.arizona@yahoo.com ${ }^{2}$
}

\begin{abstract}
Abstrak-Pada masa sekarang ini penggunaan citra RGB sudah merupakan suatu kebutuhan dalam berbagai bidang. Akan tetapi penggunaannya terkendala dengan kapasitas file yang besar, tetapi sangat dimungkinkan untuk melakukan kompresi terhadap citra yang dimiliki sesuai dengan kebutuhan. Dengan metode kuantisasi, matrik $R$, matrik $G$ maupun matrik B akan dikurangi tingkatannya, sehingga jumlah bit yang digunakan untuk merepresentasikan citra menjadi berkurang. Oleh karena jumlah bit berkurang maka ukuran file menjadi lebih kecil.Metode kuantisasi termasuk dalam kategori Lossy Compression,sehingga citra yang sudah dikompresi tidak dapat didekompresi kembali seperti semula karena ada informasi yang hilang.
\end{abstract}

Kata kunci: Metode Kuantisasi, Kompresi, Citra.

Abstract-At present the use of RGB images is a necessity in various fields. However, its use is constrained by a large file capacity, but it is possible to compress the image that is owned as needed. With the quantization method, the $R$ matrix, the $G$ matrix and the B matrix will be reduced, so that the number of bits used to represent the image will be reduced. Because the number of bits is reduced, the file size becomes smaller. The quantization method is included in the Lossy Compression category, so the compressed image cannot be decompressed again because there is information missing.

Keywords: Quantization Method, Compression, Image.

\section{PENDAHULUAN}

Citra RGB merupakan suatu matrik 3 dimensi, yakni dimensi panjang, dimensi lebar dan dimensi RGB. Jika diurai lebih lanjut, akan didapat tiga matrik dua dimensi, sebut saja matrik R, matrik G, matrik B. Masing-masing matrik akan berisi tingkat R (Red), G (Green) dan B (Blue) dari masing-masing piksel penyusun citra. Perkembangan mediapenyimpan berkapasitas besar mengakibatkan orang tidak lagi menemui masalah jika mempunyai file dengan ukuran yang besar. Lebih-lebih jika file yang dimiliki merupakan file image [1].

Walaupun demikian, adakalanya ukuran file yang besar tersebut terasa mengganggu jika harus memanage media penyimpan untuk bermacam-macam tipe data. Apalagi jika file tersebut akan dikirim secara elektronik, tentunya kapasitas file menjadi masalah tersendiri. Pada dasarnya teknik kompresi citra digunakan untuk proses transmisi data (data transmission) dan penyimpanan data (storage). Kompresi citra banyak diaplikasikan pada penyiaran televisi, penginderaan jarak jauh (remote sensing), komunikasi militer, radar dan lain-lain [2], [3].

Ada banyak metode kompresi data, salah satunya adalah metode kuantisasi. Metode kuantisasi bekerja dengan mengurangi jumlah intensitas warna, sehingga jumlah bit yang digunakan untuk merepresentasikan citra menjadi berkurang. Oleh karena jumlah bit berkurang maka ukuran file menjadi lebih kecil. Dengan berkurangnya intensitas warna tentu saja ada informasi yang hilang dari citra asal. Oleh karena itu metode ini termasuk dalam lossy compression. Oleh karena itu citra yang sudah dikompresi sulit didekompresi kembali karena adanya informasi yang hilang [4].

\subsection{Elemen-Elemen Citra Digital}

\section{LANDASAN TEORI}

Berikut adalah elemen-elemen yang terdapat pada citra digital[1]:

1. Kecerahan (brightness)

Kecerahan (brightness) merupakan intensitas cahaya yang dipancarkan piksel dari citra yang dapat ditangkap oleh sistem penglihatan. Kecerahan pada sebuah titik (piksel) di dalam citra merupakan intensitas rata-rata dari suatu area yang melingkupinya.

2. Kontras (contrast)

Kontras (contrast) menyatakan sebaran terang dan gelap dalam sebuah citra. Pada citra yang baik, komposisi gelap dan terang tersebar secara merata.

3. Kontur (countur)

Kontur (countur) adalah keadaan yang ditimbulkan oleh perubahan intensitas pada piksel-piksel yang bertetangga. Karena adanya perubahan intensitas inilah mata mampu mendeteksi tepi-tepi objek di dalam citra. 
4. Warna (color)

Warna sebagai persepsi yang ditangkap oleh visual terhadap panjang gelombang cahaya yang dipantulkan oleh objek.

5. Bentuk (shape)

Bentuk (shape) adalah properti intrinsik dari objek 3 dimensi, dengan pengertian bahwa bentuk merupakan properti intrinsik utama untuk siustem visual manusia.

6. Tekstur (texture)

Tekstur (texture) dicirikan sebagai distribusi spasial dari derajat keabuan di dalam sekumpulan pikselpiksel yang bertetangga. Tekstur adalah sifat-sifat atau karakteristik yang dimiliki oleh suatu daerah yang cukup besar sehingga secara alami sifat-sifat tadi dapat berulan dalam daerah tersebut. Tekstur adalah keteraturan pola-pola tertentu yang terbentuk dari susunan piksel-piksel dalam citra digital. Informasi tekstur dapat digunakan untuk membedakan sifat-sifat permukaan suatu benda dalam citra yang berhubungan dengan kasar dan halus, juga sifat-sifat spesifik dari kekasaran dan kehalusan permukaan tadi, yang sama sekali terlepas dari warna permukaan tersebut.

Berikut kegunaan analisis tekstur[5]:

1. Tekstur memainkan peranan penting dalam banyak tugas dalam sistem visual, seperti pemeriksaan permukaan, pengelompokan objek pemandangan, orientasi permukaan, penentuan bentuk objek.

2. Digunakan untuk segmentasi citra, mengidentifikasikan pola-pola yang teratur dan berulang, pola-pola intensitas, permukaan benda yang berhubungan dengan sifat kasar dan halus, koloni mikroba, jalan raya, bahkan sampai pada sifat permukaan bumi atau planet lainnya.

3. Untuk tujuan pengolahan citra, analisis tekstur adalah menjadikan pola variasi lokal intensitas yang berulang sebagai pembeda, manakala pola variasi tersebut terlalu kecil bila dibandingkan dengan objek yang diamati dalam resolusi yang dipakai.

Syarat-syarat terbentuknya tekstur adalah sebagai berikut:

1. Adanya pola-pola primitif yang terdiri dari satu atau lebih piksel. Bentuk pola primitif ini dapat berupa titik, garis lurus, garis lengkung, luasan, dan lain-lain yang merupakan elemen dasar dari sebuah bentuk.

2. Pola-pola primitif tadi muncul berulang-ulang dengan interval jarak dan arah tertentu sehingga dapat diprediksi serta ditemuikan karakteristik pengulangannya.

\subsection{Kompresi Citra}

Kompresi citra adalah proses pemampatan citra yang bertujuan untuk mengurangi duplikasi data pada citra sehingga memory yang digunakan untuk merepresentasikan citra menjadi lebih sedikit daripada representasi citra semula. Ada faktor mengapa citra sangat tepat dilakukan proses kompresi agar tidak terjadi korelasi yang signifikan antara pixel dengan pixel tetangga. Dan biasanya korelasi ini disebut dengan korelasi spasial. Dari faktor inilah muncul data berlebihan (Redudancy). Kompresi data dicapai dengan mengurangi redudancy (kelebihan data) tapi ini juga membuat data kurang dapat diandalkan, lebih rentan terhadap kesalahan. Membuat data yang lebih handal, disisi lain dilakukan dengan menambahkan bit cek dan bit paritas, sebuah proses yang meningkatkan ukuran kode.

\subsection{Teknik Kompresi Citra}

Ada dua teknik yang dapat dipakai dalam melakukan kompresi citra [4]:

\section{Lossless Compression}

Lossless Compression merupakan kompresi citra dimana hasil dekompresi dari citra yang terkompresi sama dengan aslinya, tidak ada informasi yang hilang. Sayangnya rasio kompresi citra metode ini sangat rendah. Banyak aplikasi yang memerlukan kompresi tanpa cacat, seperti aplikasi radiografi, kompresi citra hasil diagnosa medis atau gambar satelit, dimana kehilangan gambar sekecil apapun akan menyebabkan hasil yang tak diharapkan. Contohnya Run Lenght Encoding (RLE), Entrophy Encoding (huffman, aritmatik), dan Adaptive Dictionary Based (LZW).

2. Lossy Compression

Lossy Compression adalah kompresi citra dimana hasil dekompresi citra yaang terkompresi tidak sama dengan citra aslinya karena ada informasi yang hilang, tetapi masih bisa ditolerir oleh persepsi mata. 
Mata tidak dapat membedakan perubahan kecil pada gambar. Metode ini menghasilkan rasio kompresi yang lebih tinggi daripada metode lossless. Contohnya adalah color reduction, chroma subsampling, dan transform coding, seperti tranformasi fourier, wavelet, dan lain-lain[6].

\subsection{Kriteria Kompresi Citra}

Kriteria yang digunakan untuk mengukur pemampatan citra adalah [7]:

1. Waktu kompresi dan dekompresi

Proses kompresi adalah proses mengkodekan citra (encode) sehingga diperoleh citra dengan representase kebutuhan memori yang minimum. Citra terkompresi tersimpan dalam file dengan format tertentu, misalnya JPEG (Joint Photographic Expert Group). Sedangkan proses dekompresi adalah proses untuk menguraikan citra yang dimampatkan untuk dikembalikan lagi (decoding) menjadi citra yang tidak mampat. Algoritma pemampatan yang baik adalah algoritma yang membutuhkan waktu untuk kompresi dan dekompresi paling sedikit (paling cepat).

2. Kebutuhan memori

Metode kompresi yang baik adalah metode kompresi yang mampu mengkompresi file citra menjadi file yang berukuran paling minimal. Algoritma pemampatan yang baik akan menghasilkan memori yang dibutuhkan untuk menyimpan hasil kompresi yang berkurang secara berarti. Biasanya semakin besar persentase pemampatan, semakin kecil kebutuhan memori yang diperlukan sehingga kulitas citra semaik berkurang, dan sebaliknya, semakin kecil persentase citra yang dimampatkan, semakin bagus kualitas hasil pemampatan tersebut[8].

3. Kualitas pemampatan (fidelity)

Metode kompresi yang baik adalah metode kompresi yang mampu mengembalikan citra hasil kompresi menjadi citra semula tanpa kehilangan informasi apapun. Kalaupun ada informasi yang hilang akibat pemampatan, sebaiknya hal itu ditekan seminimal mungkin. Biasanya semakin berkualitas hasil pemampatan, semakin besar memori yang dibutuhkan. Sebaliknya, semakin jelek kualitas citra hasil pemampatan, semakin kecil kebutuhan memori yang harus disediakan.

4. Format keluaran

Format citra hasil pemampatan yang baik adalah yang cocok dengan kebutuhan pengiriman dan peyimpanan data.

\subsection{Metode Kuantisasi}

Metode ini bekerja dengan cara mengurangi derajat kebuan sehingga jumlah bit yang diperlukan untuk merepresentasikan citra menjadi berkurang [9], [10].

Algoritma metode ini adalah:

1. Buat histogram citra semula

Histogram berfungsi menggambar penyebaran nilai-nilai intensitas piksel dari citra atau bagian tertentu pada citra. Rumus yang digunakan untuk menentukan histogram citra yaitu:

$h i=\underline{n i}, i=0,1, \ldots . . L-1$

$n$

Dimana :

hi : histogram citra

$n i$ : jumlah piksel yang memiliki nilai derajat keabuan $i$

$n$ : jumlah keseluruhan piksel citra semula

$L$ : derajat keabuan yaitu dari 0 sampai $L-1$ (misal derajat keabuan 8 bit, berarti nilai derajat keabuan antara 0 sampai 255 karna 8 bit $=2^{8}=256$ ).

2. Buat beberapa kelompok untuk mendapatkan nilai intensitas baru.

Pengelompokan ini berfungsi untuk mendapatkan nilai intensitas baru yang nantinya akan menggantikan nilai intensitas lama. Adapun rumus yang digunakan untuk pengelompokkan adalah sebagai berikut :

$\underline{n}$

$L$

Dimana :

$n:$ jumlah keseluruhan piksel citra semula

$L$ : derajat keabuan citra 
3. Ganti keabuan piksel dengan keabuan kelompok yang baru

\subsection{Proses Kompresi}

\section{HASIL DAN PEMBAHASAN}

Metode kuantisasi bekerja dengan mengurangi derajat kebuan sehingga jumlah bit yang dibutuhkan untuk merepresentasikan citra berkurang. Adapun algoritma dari metode ini:

1. Buat histogram citra semula

2. Buat beberapa kelompok sehingga setiap kelompok kira-kira berjumlah $n / L$.

3. Ganti keabuan piksel dengan keabuan yang baru.

Jika metode tersebut diimplementasikan terhadap gambar 3.1 di atas yaitu beberapa piksel berukuran $6 \mathrm{x}$ 6 piksel dengan kedalaman warna 3 bit akan dikompresi menjadi 2 bit.

Chanel R(Red)

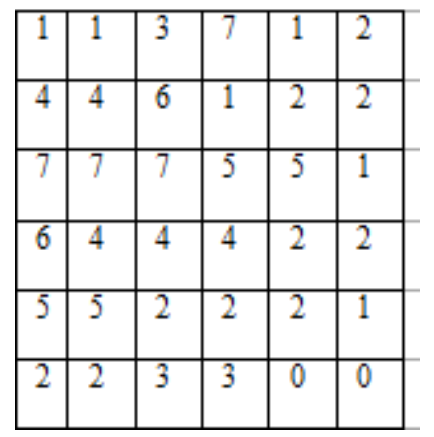

Chanel G(Green)

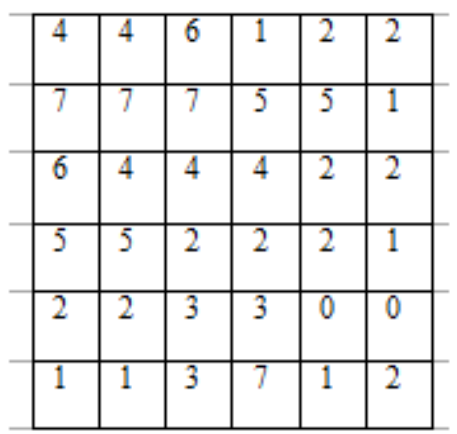

Chanel B(Blue)

\begin{tabular}{|l|l|l|l|l|l|}
\hline 7 & 7 & 7 & 5 & 5 & 1 \\
\hline 6 & 4 & 4 & 4 & 2 & 2 \\
\hline 5 & 3 & 2 & 2 & 2 & 1 \\
\hline 2 & 2 & 3 & 3 & 0 & 0 \\
\hline 1 & 1 & 3 & 7 & 1 & 2 \\
\hline 4 & 5 & 7 & 1 & 3 & 2 \\
\hline
\end{tabular}

Gambar 1. Matrik RGB

nilai intensitas citra semula dibagi menjadi 3 chanel yang masing-masing mewakili nilai Red, Green, Blue pada tiap pikselnya.

\subsection{Histogram Citra Semula}

Langkah ini bertujuan untuk menghitung berapa banyak nilai intensitas yang bernilai sama di setiap piksel pada channel red (merah), green (hijau), blue (biru) yang akan dijadikan histogram (grafik yang menunjukkan besarnya nilai $\mathrm{R}, \mathrm{G}, \mathrm{B}$ ).

\begin{tabular}{|c|l|l|l|l|l|}
\hline 1 & 1 & 3 & 7 & 1 & 2 \\
\hline 4 & 4 & 6 & 1 & 2 & 2 \\
\hline 7 & 7 & 7 & 5 & 5 & 1 \\
\hline 6 & 4 & 4 & 4 & 2 & 2 \\
\hline 5 & 5 & 2 & 2 & 2 & 1 \\
\hline 2 & 2 & 3 & 3 & 0 & 0 \\
\hline
\end{tabular}

Secara matematis untuk menghitung histogram citra dihitung dengan rumus:

$h_{i}=n_{i} / n$.

Dimana :

$n_{i}=$ jumlah piksel yang memiliki derajat keabuan $i$.

$n=$ jumlah seluruh piksel didalam citra.

Berdasarkan rumus di atas, maka untuk menentukan histogram pada chanel Red sebagai berikut :

Pada derajat keabuan $i=0, h_{i}=n_{i} / n=2 / 36=0,06$.

Pada derajat keabuan $i=1, h_{i}=n_{i} / n=6 / 36=0,17$.

Pada derajat keabuan $i=2, h_{i}=n_{i} / n=10 / 36=0,28$.

Pada derajat keabuan $i=3, h_{i}=n_{i} / n=3 / 36=0,08$.

Pada derajat keabuan $i=4, h_{i}=n_{i} / n=5 / 36=0,14$.

Pada derajat keabuan $i=5, h_{i}=n_{i} / n=4 / 36=0,11$.

Pada derajat keabuan $i=6, h_{i}=n_{i} / n=2 / 36=0,06$.

Pada derajat keabuan $i=7, h_{i}=n_{i} / n=4 / 36=0,11$.

Jika hasil perhitungan di atas ditunjukkan ke dalam tabel maka hasilnya seperti berikut. 


\begin{tabular}{|c|c|c|}
\hline$i$ & $n_{i}$ & $h_{i}=n_{i} / n$ \\
\hline 0 & 2 & 0,06 \\
\hline 1 & 6 & 0,17 \\
\hline 2 & 10 & 0,28 \\
\hline 3 & 3 & 0,08 \\
\hline 4 & 5 & 0,14 \\
\hline 5 & 4 & 0,11 \\
\hline
\end{tabular}

Gambar 2. Hasil perhitungan matriks

\subsection{Pengelompokan Nilai Intensitas}

Untuk mendapatkan nilai intensitas output, maka nilai intensitas R G B dari citra input harus dibagi menjadi beberapa kelompok, untuk menentukan jumlah pengelompokkan didapat dari rumus:

$n / L$

dimana:

$\boldsymbol{n}$ adalah jumlah piksel citra input.

$\boldsymbol{L}$ adalah derajat keabuan (bit depth) tergantung hingga berapa bit citra tersebut akan dikompresi. Karena citra sampel berukuran $6 \times 6$ piksel di atas mempunyai bit depth 3 bit $=2^{3}=2 \times 2 \times 2=8$ warna dan akan dikompresi hingga 2 bit $=2^{2}=2 \times 2=4$ warna, maka akan dibagi menjadi 4 kelompok, setiap kelompok kira-kira berjumlah 6 piksel x 6 piksel / $4=9$, seperti pada tabel di bawah ini.

Tabel 1. Pengelompokan Untuk Mendapatkan Nilai Intensitas Baru

\begin{tabular}{|c|c|c|c|}
\hline 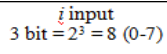 & $n_{i}$ & $\begin{array}{c}n_{i} \text { banu }= \\
n / L=36 / 4= \pm 9\end{array}$ & $\begin{array}{c}\text { i output } \\
2 \text { bit }=2^{2}=4(0-3)\end{array}$ \\
\hline 0 & 2 & \multirow[b]{2}{*}{8} & \multirow[b]{2}{*}{0} \\
\hline 1 & 6 & & \\
\hline 2 & 10 & 10 & 1 \\
\hline 3 & 3 & & \multirow[b]{2}{*}{2} \\
\hline 4 & 5 & 8 & \\
\hline 5 & 4 & \multirow{3}{*}{10} & \multirow{3}{*}{3} \\
\hline 6 & 2 & & \\
\hline 7 & 4 & & \\
\hline
\end{tabular}

\section{KESIMPULAN}

Kompresi dilakukan dengan cara menurunkan tingkat intensitas RGB secara seragam, penurun mengakibatkan bit berkurang dan file citra pun akan semakin kecil, Proses kompresi menggunakan metode kuantisasi ini dengan mengklasifikasikan intensitas warna dan mengelompokkannya sehingga mendapatkan nilai kelompok intensitas baru.

\section{DAFTAR PUSTAKA}

[1] T. Sutojo, E. Mulyanto, V. Suhartono, and O. K. I. D. W. I. NURHAYATI, “Teori Pengolahan Citra Digital.”

[2] N. J. Tuturoong, "PERBANDINGAN RASIO DAN KECEPATAN KOMPRESI MENGGUNAKAN ALGORITMA HUFFMAN, LZW DAN DMC,” TEKNO, 2010. [Online]. Available: https://ejournal.unsrat.ac.id/index.php/tekno/article/view/4320. [Accessed: 22-Jan-2020].

[3] M. Qamal, “Kriptografi File Citra Menggunakan Algoritma Tea (Tiny Encryption Algorithm),” TECHSI - J. Penelit. Tek. Inform., 2014.

[4] W. Zarman and T. Pamungkas, "IMPLEMENTASI ALGORITMA KOMPRESI LZW PADA DATABASE SERVER,” J. Ilm. Komput. dan Inform., vol. 7, no. 1, 2013.

[5] Y. Prayudi and P. S. Kuncoro, "Implementasi Steganografi Menggunakan Teknik Adaptive Minimum Error Least Significant Bit Replacement (AMELSBR)," Snati, vol. 2005, no. Snati, pp. 1-6, 2005.

[6] B. D. Raharja and P. Harsadi, "Implementasi Kompresi Citra Digital Dengan Mengatur Kualitas Citra Digital," J. Ilm. SINUS, vol. 16, no. 2, 2018, doi: 10.30646/sinus.v16i2.363.

[7] V. Lusiana, “Teknik Kompresi Citra Digital untuk Penyimpanan File menggunakan Format Data XML,” Teknol. Inf. Din., vol. 19, 
no. 2, pp. 112-119, 2014.

[8] S. I. Murpratiwi and I. M. O. Widyantara, "Pemilihan Algoritma Kompresi Optimal untuk Citra Digital Bitmap," Maj. Ilm. Teknol. Elektro, vol. 17, no. 1, p. 94, 2018, doi: 10.24843/MITE.2018.v17i01.P13.

[9] V. Lusiana and B. Hartono, "Praproses citra menggunakan kompresi citra, perbaikan kontras, dan kuantisasi piksel," Pros. SINTAK, pp. 212-216, 2017.

[10] Chandra Frenki Sianturi, "Perancangan Perangkat Lunak Kompresi Citra RGB dengan menggunakan metode kuantisasi," J. Pelita Inform., vol. 16, pp. 408-410, 2017. 